Research, part of a Special Feature on Sustainability Impact Assessment of Forest Management Alternatives in Europe

\title{
Analysis of the Impact of the Use of Eucalyptus Biomass for Energy on Wood Availability for Eucalyptus Forest in Portugal: a Simulation Study
}

$\underline{\text { Susana Barreiro }}^{1}$ and Margarida Tomé $^{1}$

\begin{abstract}
In the scope of energy diversification and profitable forest resource exploitation, increasing the use of biomass residues for energy can play an important role by using local sources of energy, reducing carbon emissions and fossil-energy use, providing additional revenue for the forest sector, and also reducing the risk of forest wildfires. Regional simulators can help forecast available wood and biomass and allow evaluation of possible future conflicts of interest and their consequences for society. This paper focuses on improving an existing regional forest simulator (SIMPLOT) so that it can be applied to study research questions related to increasing the use of eucalyptus biomass for bioenergy and the related consequences for wood available for pulp. Biomass modules were integrated into SIMPLOT so that different sources of biomass used for energy could be accounted for. The updated version of the simulator was used to assess the impact of different biomass demands for bioenergy, combined with different afforestation alternatives on the wood available for the pulp and paper industry in Portugal. SIMPLOT's forecasts indicated that the eucalyptus forest is unable to satisfy wood demand even when pulp afforestation areas are doubled, regardless of the biomass demand considered. Also, the simulation results showed that, with the tested afforestation rates, eucalyptus forest cannot meet high increases in demand for wood.
\end{abstract}

Key Words: biomass residues; energy production; eucalyptus; pulp and paper industry regional simulator; SIMPLOT

\section{INTRODUCTION}

Eucalyptus globulus was introduced into Portugal in the second half of the 19th century, but only recently, has it increased its range from around 70,000 ha in 1965 (Direcção Geral dos Serviços Florestais e Aquícolas (DGSFA) 1966a, 1966b) to 739.515 ha, making it the second-most important species in the country (Autoridade Florestal Nacional (AFN) 2010). E. globulus has assumed an important role not only in terms of forest area, but also in terms of the economy, providing the raw material for the pulp and paper industry, one of the most important industries in the country. Eucalyptus plantations have emerged as an alternative to other land uses, competing with grasslands, rain-fed agriculture, shrublands, maritime pine forest, and, more recently, as an alternative to land abandonment (Soares et al. 2007).

In recent decades, the use of biomass for energy has become a common topic. Short-rotation forestry, as part of shortrotation coppice crops, has become extremely important because biomass is seen by many European governments as having an important role in meeting commitments under the Kyoto Protocol (United Nations 1998). By 2010, Europe was expected to obtain $12 \%$ of its power production from renewable resources (Abell 2005).

The role of biomass in energy production is high in Brazil, where huge investments made in the pulp and paper industry have resulted in intensive selection programs using cloning, controlled hybridization, and micropropagation of eucalyptus (Eucalyptus grandis and Eucalyptus saligna) (Abell 2005).
In 2005, the Portuguese Energy Strategy pointed out the need to increase the power infrastructure by building 15 new thermoelectric plants supplied by forest biomass (Diário da República (DRE) 2005a). Energy produced by these plants is competitively priced (109€/MWh), only bettered by photovoltaic energy (DRE 2005b). The strategy also recommended financing research into new technologies that use forest biomass for localized energy production (DRE 2006).

Over the last three decades, forestry wood chain (FWC) industries have been using biomass to produce thermo and electrical energy in Portugal. In 2008, $74 \%$ of the energy consumed by the pulp and paper industry was derived from biofuels; of this, $81 \%$ of the energy produced from biomass derived from a subproduct of pulp production (black liquor), $17 \%$ was produced from E. globulus and Pinus pinaster bark, and the remaining $2 \%$ from shrubs and agro-industrial residues (Associação da Indústria Papeleira (CELPA) 2009).

The first biomass plant, Mortágua, started operating in 1999 with a $63 \mathrm{GWh}$ capacity and a biomass consumption of $109,000 \mathrm{Mg} / \mathrm{yr}$. This plant was followed by another three plants installed in 2007 and 2009, amounting to a total power of $380 \mathrm{GWh} / \mathrm{yr}$ and a consumption of $700,000 \mathrm{Mg} / \mathrm{yr}$. In 2010, four other biomass plants were planned to come online.

In Portugal, E. globulus stands have mainly been managed for pulp production. Unlike what happens for other species managed with other purposes in mind, E. globulus does not have restrictions on wood dimensions provided that tree tops 
are eliminated according to a predefined top diameter making it possible to use them for bioenergy. Rotation age is usually set by the development of mean and current annual volume increment, although it is difficult to set a fixed rotation age because stand growth depends on stand density and site quality. Therefore, rotation age can vary from 8 up to $14 \mathrm{yr}$ or more, depending on wood demand. Over the years, spacing trials have determined that ideal density is ca. 1200 trees, compromising between stand density and silvicultural operations costs (Ribeiro et al. 1997). Although this species has always been managed for pulp, the recent interest in bioenergy requires that a different forest management approach (FMA) was also considered in this study. Species used for bioenergy purposes are usually chosen for their resprouting ability, good biomass quality (low water content), and high productivity. Thus, high densities and shorter rotations (but not too short, in order to give it time to grow and reduce the amount of foliage) are preferred for this type of management. To date, no studies examining E. globulus's potential to be used for bioenergy have been published in Portugal.

Given current market pressure to supply pulp mills with wood and future pressure to supply bioenergy plants with biomass, it is interesting to study possible competition and conflicts between both uses for the same raw material. The main objective of this paper is to investigate the impacts of increasing biomass demands on wood available to be used in pulp production. In order to do so, the SIMPLOT regional simulator, described in Barreiro and Tomé (2011), was improved to simulate the two most intensive FMAs considered under the scope of the EFORWOOD project: even-aged forestry and short-rotation forestry (P. Duncker, S. Barreiro, G. Hengeveld, T. Lind., W.L. Mason, S. Ambroży, and H. Spiecker unpublished manuscript). Consequently, improvements to the simulator can be seen as a secondary objective of this paper.

Several alternative combinations of new annual plantation areas for wood production for pulp (WP) and for bioenergy production (BP) were studied, combined with two scenarios of biomass demand: one considering no biomass demand and the other characterized by an annual percentage increase.

\section{METHODS}

Before describing the modifications made to the SIMPLOT simulator, a brief description of the original version is presented. The description of the updated version of the model and its overall structure follows a brief introduction to biomass sources.

\section{Simulator Description}

Overview of the original SIMPLOT simulator

SIMPLOT's previous version has been described in detail by Barreiro and Tomé (2011). It is a non-spatially explicit regional simulator conceived to use national forest inventory plots as input. It was designed to simulate the development of all types of eucalyptus stands in 1-year time steps by using growth models. For the simplicity of the simulator's growth module, the area of mixed stands, not very significant compared with the area of pure stands, is converted into area of pure stands, based on the ratio between eucalyptus volume in the stand and the total stand volume. The evolution of forest resources is mainly driven by wood demand, also considering other drivers, e.g., fire occurrence, land-use changes (LUC), and forest management changes. Drivers are organized in separate modules and implemented in two steps: the total amount of the drivers, which represents the module's inputs; and the probability of occurrence of the event for each stand, usually set by a probability function and implemented with Monte Carlo simulation. If an event occurs, the simulator takes a specific action depending on the event. The influence of the drivers is expressed through the scenario, and simulation runs depend on a series of user-defined parameters. The simulator assumes beforehand that only stands that have reached the number of rotations defined by the user can be either abandoned, replanted under the same FMA, or changed to a different one. Furthermore, SIMPLOT works based on a set of implicit assumptions, namely, burned stands are harvested, salvage wood is considered, and surplus harvested biomass is left on site to offset nutrient removal.

\section{Improvements made to SIMPLOT}

The previous version of SIMPLOT did not consider the use of biomass. Biomass can be allocated from different sources: forest residues (Source $e_{\text {Residues }}$ ), bioenergy plantations (Source Energy $_{\text {, }}$, and wood-production forests for pulp $\left(\right.$ Source $\left._{\mathrm{Wood}}\right)$. Forest residues are composed of biomass deriving from burned stands not used by the pulp industry, biomass from tree tops, branches, and bark resulting from harvesting depending on the harvesting method, and biomass resulting from shoot selection operations in coppice stands. To integrate these three sources of biomass for energy in the simulator, different methodologies were applied, depending on the source.

So that SIMPLOT could simulate the use of biomass, several significant improvements were made: (1) biomass demand and annual plantation of areas for energy purposes were included as drivers in the scenario, and simulation parameters, mostly concerning short-rotation forestry, were added; (2) biomass ratio functions, which predict the biomass of a tree component below a given height (and therefore to a certain diameter), were integrated so that biomass residues could be accounted for; (3) a growth model was added to simulate the growth of stands used for bioenergy production; and (4) two harvesting modules were created to harvest stands for bioenergy.

It was necessary to include an assumption concerning the harvesting of wood-production plantations for energy: if 
Fig. 1. Simplified overall structure of SIMPLOT simulator.

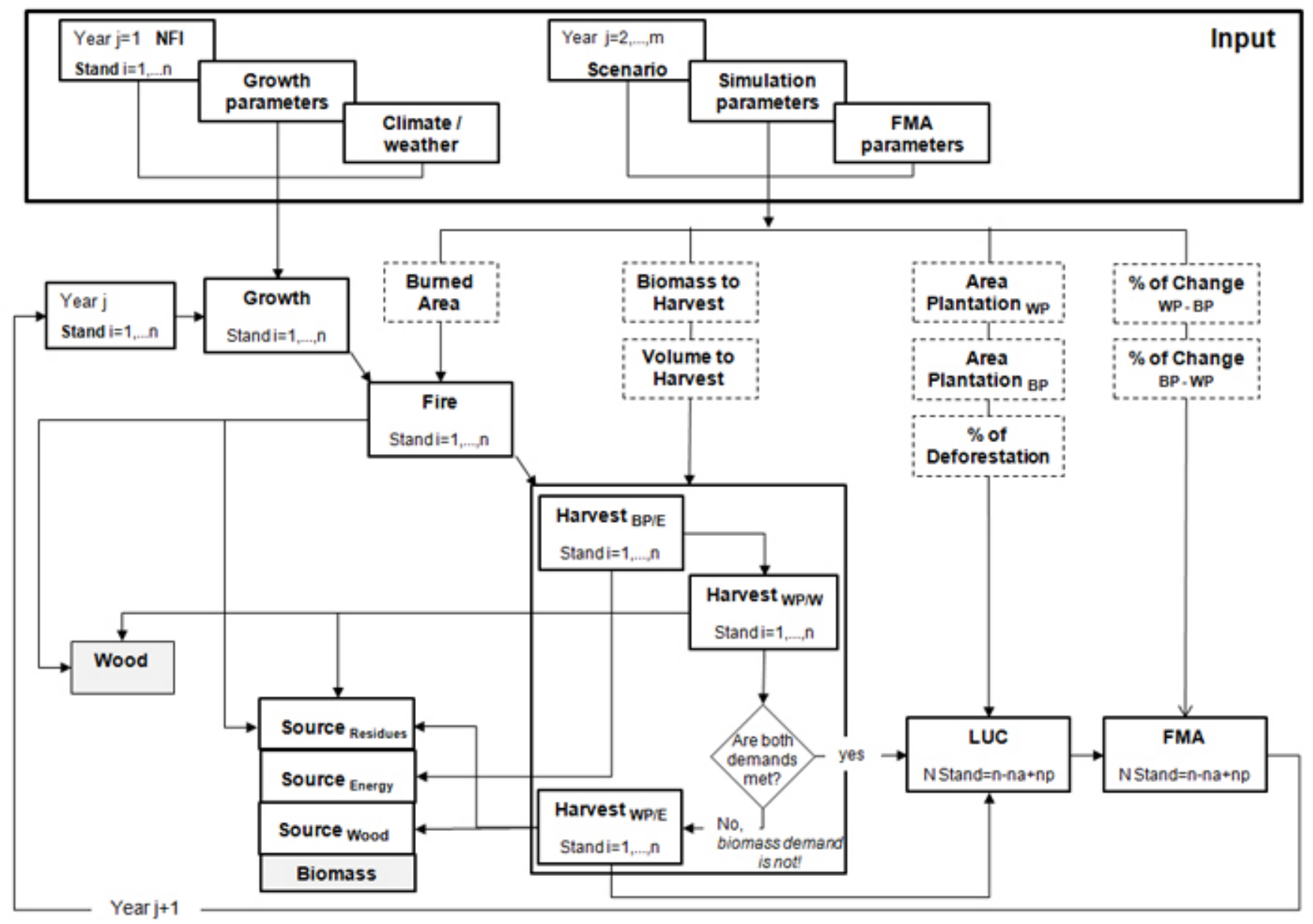

With BP/E, WP/W and WP/E representing bioenergy plantations used for energy, wood-production plantations used for wood and wood-production plantations used for energy, respectively.

biomass demand is not met using biomass from Source Residues and Source $_{\text {Energy }}$, wood-production forests can be harvested for energy as long as wood demand has been met. Another assumption was made, this one related to fire: biomass of leaves is totally destroyed, but bark and branches are damaged, suffering biomass reductions of $40 \%$ and $25 \%$, respectively.

After the improvements, SIMPLOT now includes two demands to be met for the horizon of simulation: wood demand for pulp and paper production and biomass demand for bioenergy production. Fig. 1 shows the current structure of the simulator, including the new modules and each module's contribution to meet the wood and biomass demands. The first three boxes represent the input files. The next level of boxes deriving from the scenario and simulation parameters input files show the total amount of each driver needed as input for each of the drivers' modules. The cascade boxes represent the modules, and the arrows indicate the order in which each of the modules run: first, the growth module, followed by the modules related to the drivers: fire, harvest bioenergy plantations (BP/E), harvest wood-production forests for pulp production (WP/W), harvest wood-production forests for energy production (WP/E), LUC, and changes in FMAs.

Simulation parameters, drivers, and scenarios

The scenario input file containing the information to run the driver's modules has been restructured. Inclusion of the shortrotation FMA was followed by a need to specify the total amount of biomass for bioenergy production to be harvested in each year of simulation (representing the biomass demand for energy) and the area of new bioenergy plantations. Apart from these changes, the proportions of area related to the conversion of even-aged (WP) to short-rotation (BP) and the inverse have also been included. Fig. 2 gives a more detailed overview of the present functioning of the simulator. 
Fig. 2. Schematic view of SIMPLOT's functioning.

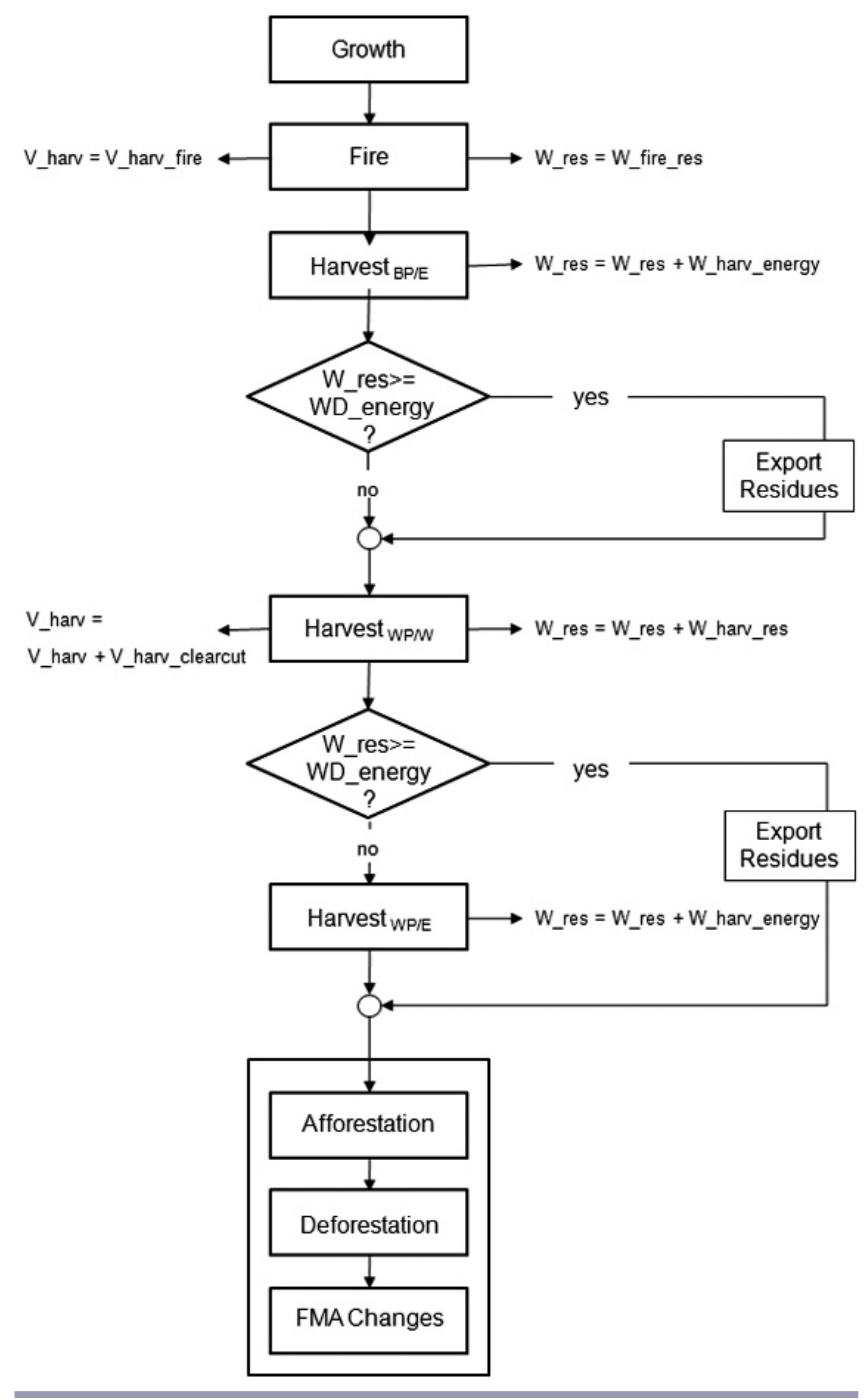

The new user-defined parameters concerning short-rotation forestry are: rotation length, starting density, and number of rotations. The assortments and the harvesting system have also increased the previous list. At present, apart from top diameter it also integrates log length and four dummy variables that are used to define the possible harvesting systems: (1) top (over bark wood); (2) branches (of the whole tree including leaves); (3) bark (of the whole tree except top bark); and (4) top with branches (the whole top including bark, branches and, leaves).

\section{Biomass ratio functions}

In the previous version of the simulator, there was an amount of biomass residues resulting from harvested stands, but this material was not accounted for. In the present version, this material is estimated and assumed to be used for bioenergy production representing one of the three sources of biomass.
In order to calculate the percent biomass, tree biomass ratio equations depending on the top diameter were used (L. Fontes, M. Tomé, J. Tomé, and M. B. Coelho unpublished manuscript). The biomass of tops is estimated per tree component: wood, bark, branches, and leaves. The equations are applied to the mean tree and the total biomass of residues is then estimated from the number of trees per hectare. In order to implement the biomass ratio equations, height of the mean tree (Tomé et al. 2007b), height up to the crown base (Soares and Tomé 2003), diameter of the dominant trees (Tomé et al. 2007a), and top height need to be determined. In this study, $\operatorname{logs} 2 \mathrm{~m}$ long were considered. The diameter at the base of each $\log$ (di) along the stem is calculated until the top diameter planned for harvesting is surpassed. The diameters (di) were calculated over bark with existing taper equations (Tomé et al. 2007b). The height of the last log was selected from the bottom or the top of the previous log so that a top diameter as close as possible from the one planned could be obtained. All equations used can be found in Table 1 .

This improvement allows considering different harvesting systems from more to less intensive biomass removal, depending on the amount of residues removed from the site.

\section{Growth module update}

In SIMPLOT's previous version, the growth module integrated growth models for uneven-aged stands and for pure, even-aged stands (wood-production forests). This version comprises an adaptation of the Globulus 3.0 (Tomé et al. 2006) model in order to produce more accurate estimates for very dense, pure, even-aged stands (Barreiro 2012), which is used to simulate the growth of stands used for bioenergy production.

\section{Running the simulator}

After updating stand growth with the growth module, the first driver module to run is "hazards-fire." This module was updated to produce two different outputs. After deciding which stands are burned (Monte Carlo simulation), it separates the volume of salvage wood to be used for pulp from the biomass of residues for bioenergy production. The biomass of residues resulting from harvesting a certain proportion of burned wood for industrial use, combined with the total biomass from the stands with no industrial use, is taken into account, contributing to the first source of biomass for energy.

The next three modules in Fig. 1 are harvesting modules. The first one (harvest $\mathrm{BP} / \mathrm{E}$ ), is responsible for harvesting bioenergy stands consisting of the second source of biomass for energy. This module harvests all stands planted for energy production that have reached the rotation length defined as a simulation parameter, regardless of the biomass demand defined in the scenario. The aboveground biomass resulting from this harvest operation is summed up to the burned biomass previously harvested, and compared with the biomass demand. If biomass demand has been met, the surplus biomass 
Table 1. Equations used in the calculation of E. globulus residues biomass

$$
\begin{aligned}
& \text { (Tomé et al. 2007a): }
\end{aligned}
$$

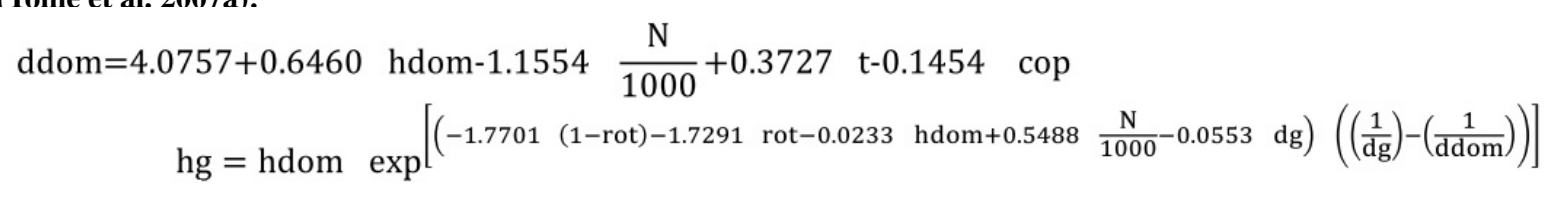

$$
\begin{aligned}
& \mathrm{h}_{\mathrm{c}}=\mathrm{h}\left(1-\left(\frac{1}{1+\exp \left(-\left(-5.7611-0.1754 \text { hdom }-0.2718 \frac{\mathrm{N}}{1000}+12.3341 \frac{1}{\mathrm{t}}-0.2056 \mathrm{dg}\right)\right)}\right)\right.
\end{aligned}
$$

\section{(Tomé et al. 2007b):}

$$
\mathrm{d}_{\mathrm{i}}=\operatorname{dg}\left(1.4409+0.3535 \ln \left(1-\left(\frac{\mathrm{hi}}{\mathrm{hg}}\right)^{\frac{1}{7.7840}}\left(1-\mathrm{e}^{\frac{-1.4409}{0.3535}}\right)\right)\right)
$$

\section{(L. Fontes. M. Tomé. .I. Tomé. and M. B. Coelho unvublished manuscrivt):}

$$
\begin{aligned}
& \frac{\mathrm{W}_{\mathrm{w} \mathrm{di}}}{\mathrm{W}_{\mathrm{w}}}=1-\left(1-\left(\frac{\mathrm{h}_{\mathrm{i}}-\mathrm{h}_{\mathrm{st}}}{\mathrm{h}-\mathrm{h}_{\mathrm{st}}}\right)^{1.0430}\right)^{2.4545} \\
& \frac{\mathrm{W}_{\mathrm{b} \mathrm{di}}}{\mathrm{W}_{\mathrm{b}}}=1-\left(1-\left(\frac{\mathrm{h}_{\mathrm{i}}-\mathrm{h}_{\mathrm{st}}}{\mathrm{h}-\mathrm{h}_{\mathrm{st}}}\right)^{0.8507}\right)^{2.0807} \\
& \frac{\mathrm{W}_{\mathrm{br} \mathrm{di}}}{\mathrm{W}_{\mathrm{br}}}=1-\left(1-\left(\frac{\mathrm{h}_{\mathrm{i}}-\mathrm{h}_{\mathrm{c}}}{\mathrm{h}-\mathrm{h}_{\mathrm{c}}}\right)^{1.7933}\right)^{2.3417} \\
& \frac{\mathrm{W}_{\mathrm{ldi}}}{\mathrm{W}_{\mathrm{l}}}=1-\left(1-\left(\frac{\mathrm{h}_{\mathrm{i}}-\mathrm{h}_{\mathrm{c}}}{\mathrm{h}-\mathrm{h}_{\mathrm{c}}}\right)^{2.1388}\right)^{2.6899} \\
& \mathrm{Wa}_{\mathrm{di}}=\mathrm{W}_{\mathrm{w} \mathrm{di}}+\mathrm{W}_{\mathrm{b} \text { di }}+\mathrm{W}_{\mathrm{br} \mathrm{di}}+\mathrm{W}_{\mathrm{l} \mathrm{di}}
\end{aligned}
$$$$
\text { If } h_{i} \leq h_{c} \text { then } \frac{w_{i d i}}{w_{i}}=0 \text { where } \mathrm{i}=b r, l
$$

where $\mathrm{N}$ is the stand density $\left(\mathrm{ha}^{-1}\right)$; hdom is the dominant height $(\mathrm{m})$; $\mathrm{t}$ is the stand age (years); $\mathrm{dg}$ is the quadratic mean dbh (cm); cop is a dummy variable for coppice, assuming the value 0 for planted stands and 1 for coppice stands; $h$ is the total tree height of the average tree $(\mathrm{m}) ; h_{\mathrm{st}}$ is the stump height considered $0.15 \mathrm{~m} ; \mathrm{h}_{\mathrm{c}}$ is the tree height up to the base of the crown (m); $h_{i}$ is the top height (m); $d_{i}$ is a top diameter $(\mathrm{cm}) ; \mathrm{w}_{\mathrm{idi}}$ is the biomass of the component below diameter $\mathrm{d}_{\mathrm{i}}\left(\mathrm{Mg} \mathrm{ha}^{-1}\right)$ and where $\mathrm{i}$ represents: $\mathrm{w}$ for wood, $\mathrm{b}$ for bark, br for branches and 1 for leaves; $w_{d i}$ is the aboveground biomass below a top diameter $d_{i}$.

is considered to be available for export. If not, the harvested biomass will continue being increased by biomass outputs from subsequent modules until the corresponding demand is met.
This module is followed by the one responsible for harvesting stands for pulp production (harvest WP/W). It produces two outputs: harvested volume, which is added to the volume of salvage wood that resulted as an output from the fire module, and biomass of residues, including shoot selection biomass. 
This last biomass output also contributes to the first source of biomass if biomass demand still needs to be met. Alves (1996) determined that, in one spacing trial (500 to 1667 trees/ha), the amount of biomass removed during this operation compared with the total standing dry biomass ranges between $47.57 \%$ and $57.41 \%$, with an average value of $53.24 \%$, and no pattern in variation from the higher to the lower densities. In the absence of other information, and after discussion with forest experts, this value was used for the whole country to account for this pool of biomass. Harvesting takes place based on an age-dependent probability, selecting stands with Monte Carlo simulation. The module runs until wood demand is met, and as it runs, biomass residues are produced. This biomass output, together with the biomass resulting from burned stands, contributes to the first source of biomass.

At this point, the total harvested biomass is compared with the biomass demand, and if it has not reached the amount defined in the scenario, another harvesting module can be run. Module harvest WP/E is responsible for harvesting pulp stands for energy production. Running this module will depend on whether wood demand has been met and biomass demand has not. Thus, it ensures that pulp stands will only be used for energy if there is enough wood to supply the wood demand. This module is based on the same principles as the previous one, with the difference that the whole harvested material is used for bioenergy. The product of this module makes up the third source of biomass.

After running the modules responsible for meeting the two demands, the modules responsible for land use are run: afforestation and deforestation. Presently, the afforestation module has to take into account two different kinds of stands to be planted: wood-production stands (WP) and short-rotation bioenergy production stands (BP). This module runs under the same principles described in Barreiro and Tomé (2011), but it has been updated so that new bioenergy plantations are set according to the areas defined in the scenario for each FMA. The deforestation module has not been modified.

Finally, the last module to run is the change between FMAs, which defines the percentage of change between FMAs for each year of the simulation period. The main input information in the FMA algorithm is the percentage of transition from one FMA to another. Thus, the next step is to determine the area in hectares and the corresponding number of stands that are converted from WP to BP and from BP to WP for each year of simulation. Monte Carlo simulation is used to decide which stands are converted to a different management approach.

It is important to stress that, if biomass demand is met at any point during the simulation for a given year, biomass from shoot selection and harvesting residues is assumed to be left on site to minimize nutrient removal.

\section{Methods used for testing the simulator}

\section{Input data}

The simulations were done using national forest inventory (NFI) eucalyptus plots from NFI1997-98 as input. This case study includes a total of 786 plots, representing pure-even and uneven-aged stands and also eucalyptus mixed stands, covering an area of 805,546 ha (area equivalent to 674,908 ha of pure stands). All plots were classified as wood-production forest (WP). Biomass production (BP) stands will be represented by bioenergy plantations simulated based on the area of new plantations defined in the scenarios for each year of simulation.

\section{Scenarios and simulation parameters description}

In order to facilitate the analysis, the total amount of the drivers' wood demand, hazards-fire, and deforestation are considered equal for the different scenarios. From 1998 to 2008 wood consumption, burned areas and LUC are based on the national forest statistics (Pereira et al. 2010). Changes between different FMAs were considered null throughout the simulation period. The underlying assumptions related to each of the drivers are described below.

Wood demand evolution from 2008 onward is based on the production capacity increase announced until year 2010 by the pulp and paper mills (Altri 2010). From 2010 onward, there is a $0.3 \%$ increase per year. As for hazards-fire, the simulation of burned areas from 2008 onward was based on the analysis of historical data from 1963 on forest fires (excluding the very large fires of 2003 and 2005), and Monte Carlo simulation was used to generate a time series of eucalyptus burned areas with two medium-high severity fires occurring in this period (Fig. 3 ). Deforestation is defined as a proportion of the total forest area. This proportion, considered constant for the simulation period, was determined by multiplying the average deforestation registered for the period of 1986-2000 (Pereira et al. 2010) by the total annual forest area.

Until 2015, biomass consumption was estimated based on the capacity of the biomass plants operating or planned to be operating in the near future (Campilho, personal communication). After 2015, an annual increase of $0.9 \%$ was applied (BD1). A scenario considering no biomass demand (BD0) was also studied (Fig. 3). Because there is no information on the amount of biomass consumed per species by bioenergy plants, it was considered that $50 \%$ of the raw material came from eucalyptus. This option relates to the fact that $51 \%$ of total forest area is covered with E. globulus and Pinus pinaster, which are the species used for bioenergy. The harvesting system considered in this study is characterized by removal of bark, branches, and tree tops. Because the objective was to assess the maximum biomass available, a removal efficiency of $100 \%$ was assumed, as well as total use of the material resulting from the shoot selection operation. 
Fig. 3. Evolution of wood and biomass demands and burned area drivers.
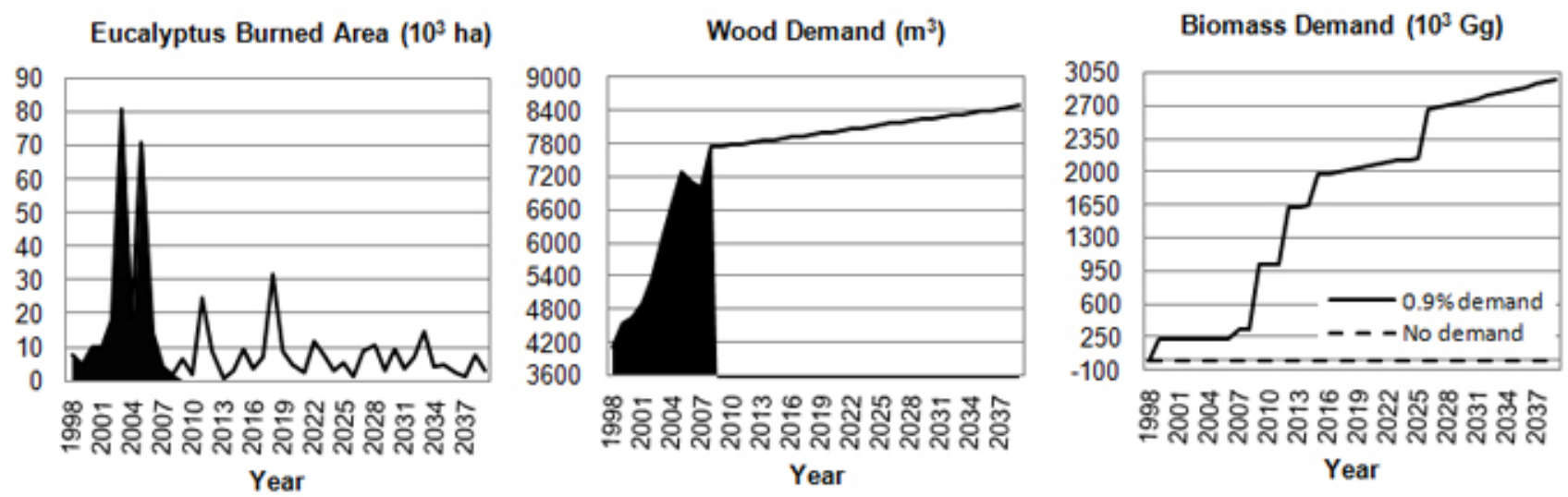

Total afforestation results from the sum of new plantations for energy and new plantations for pulp. Afforestation scenarios were based on the average of new eucalyptus areas planted between 1995 and 2000 (Pereira et al. 2010): 4833.3 ha year ${ }^{-1}$. Another three levels of new plantations were considered: $33 \%$, $66 \%$, and $100 \%$ increases over this amount. Within each of the four afforestation levels, four different bioenergy plantation amounts were tested (Fig. 4), resulting in 16 alternative scenarios that were run with a $0.9 \%$ increase in biomass demand (BD1). Additionally, four plantation scenarios excluding bioenergy plantations were combined with a no biomass demand scenario. A total of 20 scenarios were identified and named after the biomass demand combined, the plantation scenario for pulp and the plantation scenario for bioenergy.

Details on each FMA with a summary of the silvicultural operations can be found in Table A.1 in the Appendix. All scenarios were tested with the simulation parameters described in Table A.2 in the Appendix.

SIMPLOT was stochastically run in an attempt to illustrate natural variability through multiple simulation runs performed for each scenario. Outputs were averaged by scenario.

\section{RESULTS}

Applying SIMPLOT to the scenarios with different levels of new wood-production and bioenergy plantations allowed plotting wood volume available for harvest against wood demand for the two biomass demand scenarios (Figs. 5 and 6).

According to the projections, the potential wood volume between years 2018 and 2021, depending on the scenario, is not enough to satisfy wood demand. The amount of wood harvested is unstable and presents a cyclic behavior.

For the no biomass demand scenario (BD0), four pulp plantation levels were combined with the null bioenergy plantation level. None of these scenarios succeeded in meeting wood demand. However, as the area of new wood-production plantations increased, the volume deficit was reduced (Fig. 5).

The simulated harvested volume under BD1 for the same combination of plantation levels used in the BD0 scenario indicated a similar pattern throughout the simulation period (Fig. 6). Nevertheless, volume deficits are more severe under BD1 because the wood-production forest was responsible for supplying both wood and bioenergy demands.

The remaining 12 afforestation levels combined with BD1 showed the same cyclical behavior, with peaks of harvested volume nearly reaching wood demand after 2018 for some of the scenarios (Fig. 6). The highest levels of new woodproduction plantations increased the potential volume to be harvested; in fact, the scenarios that allowed getting closer to meeting wood demand were those with areas of new woodproduction plantations $>6444$ ha year ${ }^{-1}$. Moreover, for the same level of new pulp planted areas, the amount of wood available for pulp increased with the areas planted for bioenergy. This was mainly because the use of pulp planted stands for bioenergy was avoided when biomass deriving from bioenergy plantations was available.

The cyclical behavior of simulated harvested volume results from the forest area fluctuations by age class combined with forest productivity. After 2011, a reduction in forest area for the older age classes can be observed. Consequently, from 2021 onward, just the area from age class 8 is harvested, except for the years 2026 and 2036 (Fig. 7). For these years, the distribution of forest area by age class allows going back to harvesting again in age class 9 , which justifies the peaks of harvested volume observed in Fig. 6. The distribution of eucalyptus area by age class, together with an average yield of around $10 \mathrm{~m}^{3} \mathrm{ha}^{-1}$ year $^{-1}$ at age 10 supports the idea that forest resources were being depleted. 
Fig. 4. Evolution of the alternative afforestation scenarios resulting from the combination of four bioenergy production planted areas $(0,1611,3222$, and $4833 \mathrm{ha}$ ) with different levels of wood-production planted areas varying between 0 and 9666 ha in order to achieve total afforestation levels of 4833, 6444, 8055, and 9666 ha.
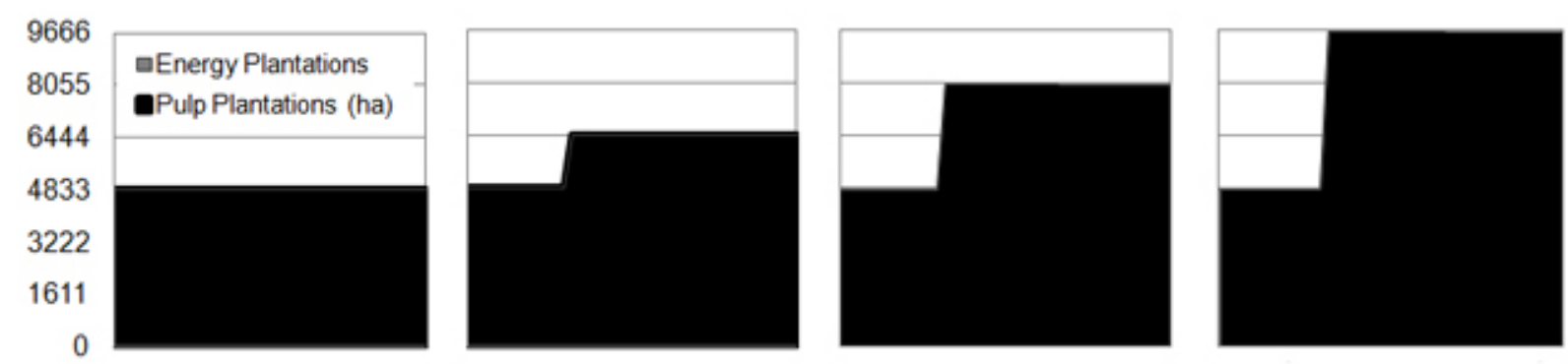

$\stackrel{\oplus}{\mathrm{C}}$
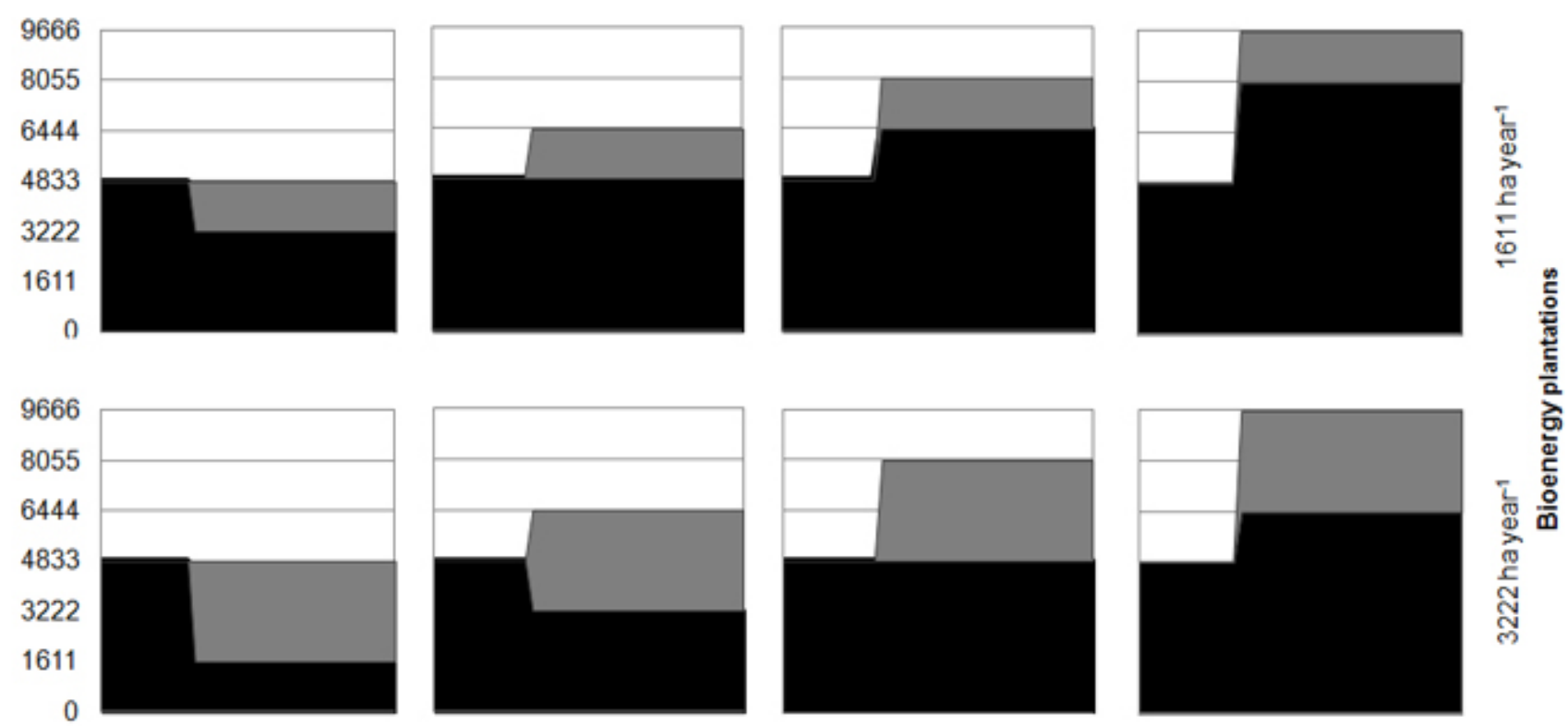

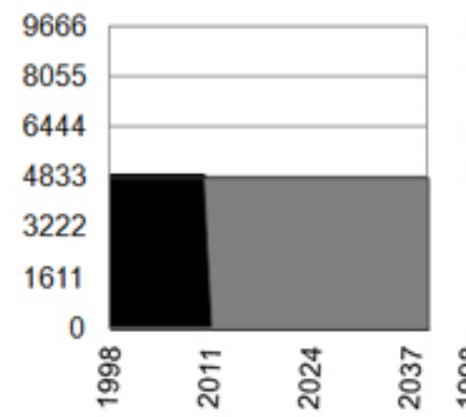

4833 ha year $^{-1}$
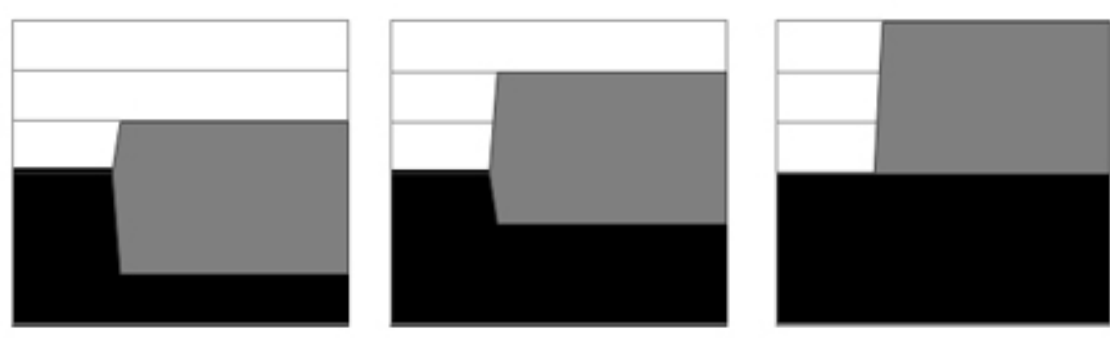

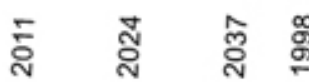

8055 ha year $^{1}$

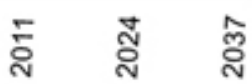

9666 ha year $^{-1}$

Total afforestation 
Fig. 5. Evolution of wood demand and harvested volume under the no biomass demand scenario combined with the four pulp afforestation scenarios considering no plantations for bioenergy.

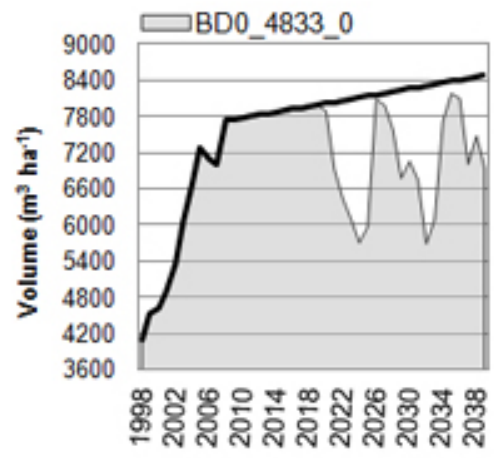

4833 ha year-1 $^{-1}$
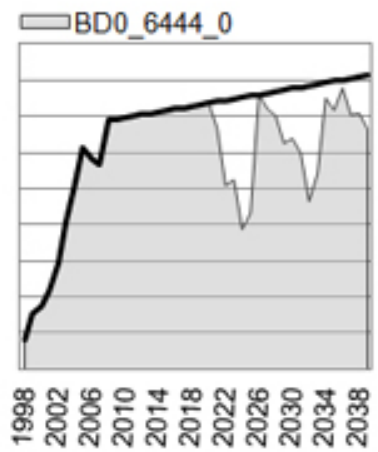

6444 ha year-1 $^{-1}$
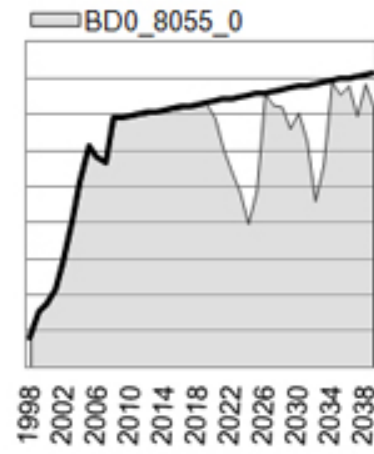

8055 ha year-1

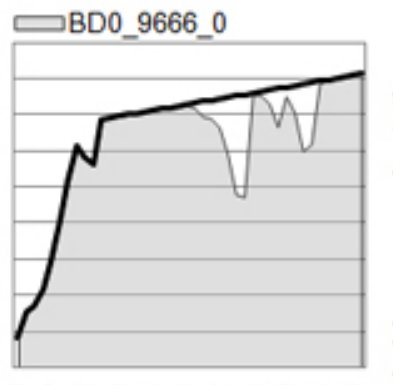

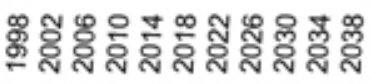

9666 ha year ${ }^{-1}$

Total afforestation

The use of biomass for energy was graphically analyzed by source of biomass (Fig. 8).

Forest residues $\left(\right.$ Source $\left._{\text {Residues }}\right)$ that comprise burned and harvesting plus thinning residues proved to be the biggest contributor for bioenergy supply. This justifies the problem of meeting biomass demand when wood demand in no longer secure because, if there were no stands to be harvested for wood supply, no residues would be produced to increment the Source $_{\text {Residues}}$.

Results showed a high amount of soil residues present during the first decade of simulation. On one hand, this reflected the reduced consumption given the small number of bioenergy plants operating at that time, and on the other hand, the high amount of biomass residues resulting from severe forest fires. The two soil biomass peaks represent the severe forest fires of 2003 and 2005. Also, simulated soil residues showed a drastic drop as biomass demand increased, indicating the use of residues as a biomass source.

Whenever there was not enough biomass in the Source ${ }_{\text {Residues}}$, new wood-production plantations for pulp were responsible for securing biomass supply, which was highlighted under the scenarios of no plantations for bioenergy. This explains the more negative impacts in terms of available volume registered for no bioenergy plantations scenarios under BD0 and BD1. Also, wood-production plantations helped satisfy biomass demand whenever biomass deriving from Source Residues $_{\text {and }}$ Source $_{\text {Energy }}$ was unable to cope with the needs.

For a given pulp plantation area, the negative impact of using biomass for energy can by partially offset by the increase in bioenergy plantations (BD1_4833_0, BD1_4833_1666, BD1_4833_3222 and BD1_4833_4833).

Simulations showed that the BD1 harvested volumes were considerably lower than the ones from BD0, which indicated the negative impact of bioenergy demand on the potential volume to be harvested for pulp. Volume deficits are considerably smaller for higher pulp plantation levels. So, in terms of wood demand, the best scenario is the one considering the highest pulp plantation level, BD1_9666_0. However, if the objective is to maximize the two demands, the choice would fall upon a scenario combining a favorable pulp plantation level with a reasonable bioenergy plantation such as 6444 ha of wood-production areas combined with 3222 ha for bioenergy (BD1_6444_3222).

\section{DISCUSSION}

The objective of this simulation study was to assess the impact of using biomass for energy on wood available for the pulp industries. In this sense, some of the assumptions and constraints were established in order to guarantee maximum biomass removal. In this study, the different scenarios were forecast based on several assumptions, and some constraints that must be accounted for when explaining the results obtained. The most important points to note are the lack of statistics related to biomass demand and also the lack of knowledge about the quantity of eucalyptus consumed by the bioenergy plants.

It was considered that as bioenergy demand increased, more harvesting residues were removed from the forest soil, contributing to the Source $_{\text {Residues }}$. This is shown by the decline in soil residues as biomass demand increases (Fig. 8). In 
Fig. 6. Evolution of wood demand and harvested volume under the $0.9 \%$ biomass demand scenario combined with 16 afforestation scenarios varying in the proportion of wood-production and bioenergy plantations.
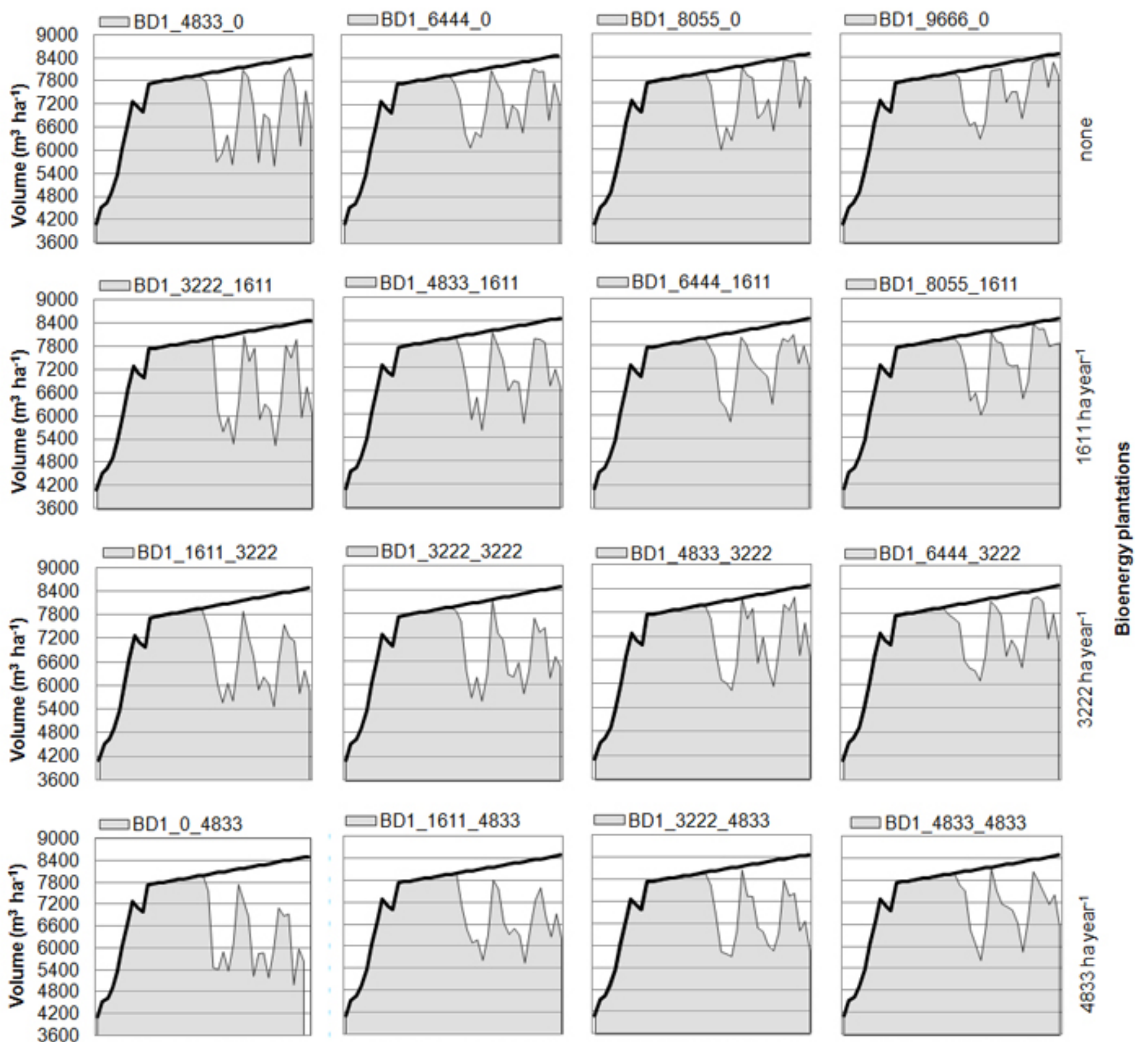

\section{$\stackrel{\boxplus}{\check{c}}$}
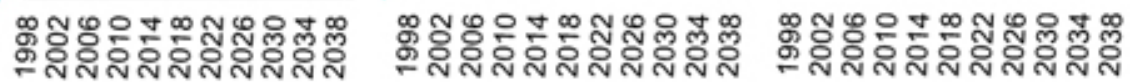

4833 ha year $^{-1}$

6444 ha year $^{-1}$

8055 ha year $^{-1}$

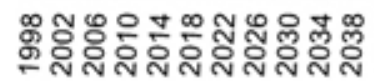

\section{Total afforestation}

reality, the removal of soil residues is usually less intensive in stands managed for pulp, as was observed in this study. First, the most intensive harvesting method, responsible for the removal of tops, bark, and branches of the whole tree, was considered, whereas it is common for bark or tops to be left on the soil. Second, the biomass resulting from the shoot selection operation was considered to fully integrate the Source $_{\text {Residues, }}$, whereas in most cases it is left on the soil because of high transportation costs. Finally, when harvesting residues 
Fig. 7. Distribution of area by age class and stand type for a scenario considering 6444 ha of new plantations for pulp combined with 3222 of new bioenergy plantations (BD1_6444_3222) for some years of simulation. Areas refer to the end of the year after harvesting has occurred.

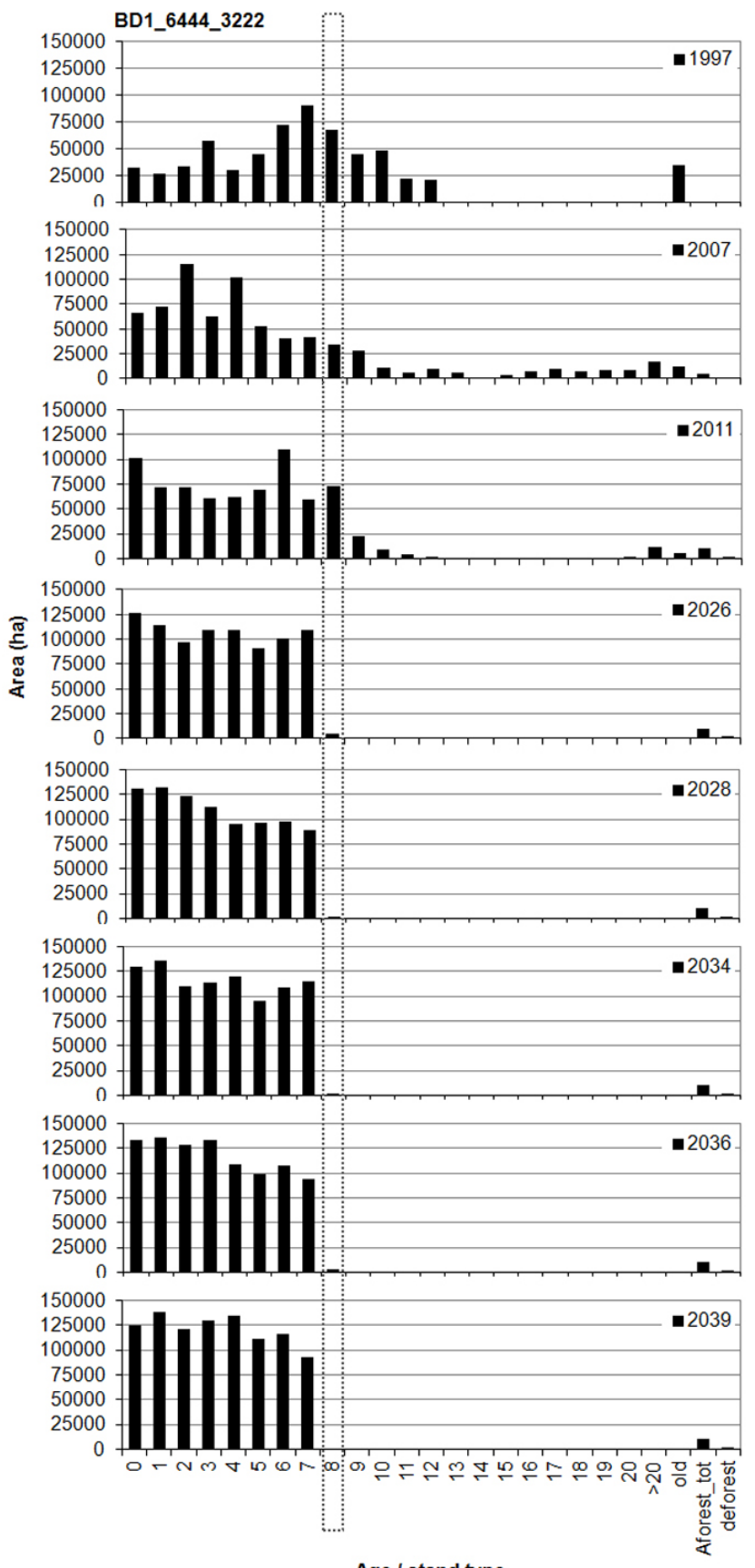

Age / stand type are removed, the efficiency of the operation is always less than $100 \%$. However, if some biomass components had been left on the site, bigger contributions would have had to come from other sources to satisfy biomass demand, namely from stands planted for bioenergy or even from those planted specifically for pulp. If harvesting residues are left on the soil, nutrient removal is reduced, and they also help protect against soil erosion. Even though recent studies have shown that, for Mediterranean conditions, retaining harvest residues on the soil surface does not increase tree growth compared with removing it (Jones et al. 1999, Madeira et al. 2010), only the incorporation of harvest residues, despite the negative effects caused by harrowing, show a positive effect on tree growth (Madeira et al. 2010). In turn, bioenergy plantations (Source $_{\text {Energy }}$ ) were assumed to be more intensively managed than pulp stands (see Table A.2 in the Appendix) based on the type of management practiced for willow (Salix sp.) and poplar (Populus sp.) in northern Europe, removing all aboveground biomass from the site without any environmental concerns.

However, these assumptions have no implications for productivity projections because SIMPLOT, being based on empirical growth models, does not have the flexibility to adequately account for nutritional issues. Furthermore, the assumption did not have a negative effect on biodiversity as the removal of harvesting residues has been proven not to reduce understory species diversity (Carneiro et al. 2007).

Most $(73 \%)$ Portuguese forests are privately owned, with privately owned eucalyptus forests belonging to two types of ownership: (1) those who make the investment without maintenance concerns and collect the profits of final felling; and (2) those who make the investment, manage the forest, and cut it whenever an unexpected need arises (Baptista and Santos 2005). In this context, and despite the pulp and paper industries being responsible for the sustainable management of 154.45 thousand ha of eucalyptus forest (CELPA 2011), sustainable forest management is difficult to achieve at the national level without negative consequences for forest productivity. Furthermore, some forest owners have started selling their wood for bioenergy purposes because it pays off. However, given biomass energetic efficiency, and despite the climatic impact policies that encourage the use of biomass for energy, biomass should be used for heat production and cogeneration instead of dedicated electricity production. Moreover, the use of wood in industries brings about more added value and higher employment in the forest sector than if it were used for energy production (Fig. 9). For the abovestated reasons, this study also assumed that pulp stands could be harvested for bioenergy production $\left(\right.$ Source $_{\text {Pulp }}$ ) when wood demand had already been satisfied. As a consequence of this assumption, biomass deriving from Source Pulp $_{\text {was }}$ used to satisfy the corresponding demand for scenarios with bioenergy plantations of less than 1611 ha year $^{-1}$ (Fig. 8). 
Fig. 8. Evolution of harvested biomass by biomass source: SourceResidues; SourceEnergy and SourcePulp. B_demand is the biomass demand and B_soil is the biomass of the residues that are left on the soil.

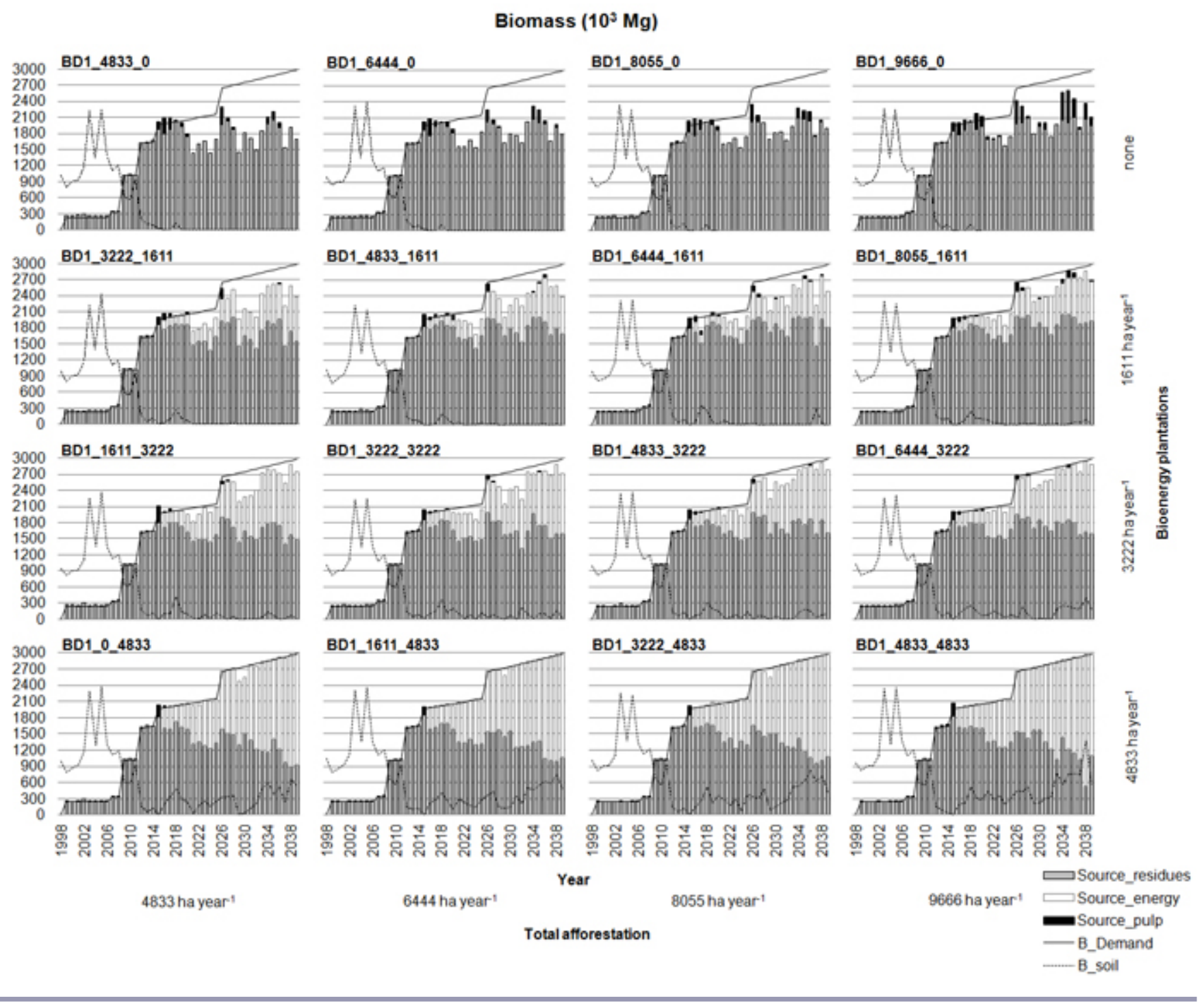

Apart from the assumptions on which SIMPLOT was based, a few constraints set by simulation parameters should also be discussed, such as the minimum age for harvesting and the harvesting probabilities, as well as the harvesting method. Portuguese eucalyptus forests are experiencing an overharvesting situation that has been mentioned in other studies (Nabuurs et al. 2007). When wood demand is not met, this means that not enough volume, or no volume at all, was harvested for that year. Analyzing the distribution of areas by age classes, BD1_6444_3222 scenario as an example (Fig. 7), it is clear that stand structure has suffered an enormous change that started with the big fires of 2003 and 2005 and was thereafter accentuated by the harvesting pressure to satisfy wood demand. After 2021 there was not enough volume available to meet wood demand because there was no area in the age classes older than 8 years. This can be explained by the minimum age for harvesting assumed in the simulations that was set at the age of 8 years and by a higher harvesting priority that was established for older stands.

As long as forests ensure meeting wood demand the first source of biomass is guaranteed up to some extent, otherwise there might be the need to plant specifically for energy. In this case, it might be wise to choose a different eucalyptus variety or even to a different species. According to some studies there are eucalyptus species other than E. globulus with better coppicing ability and higher yields (Sims et al. 1999). 
Fig. 9. Compared added value and employment related to the pulp and paper industry and bioenergy (adapted from CELPA (2006)).

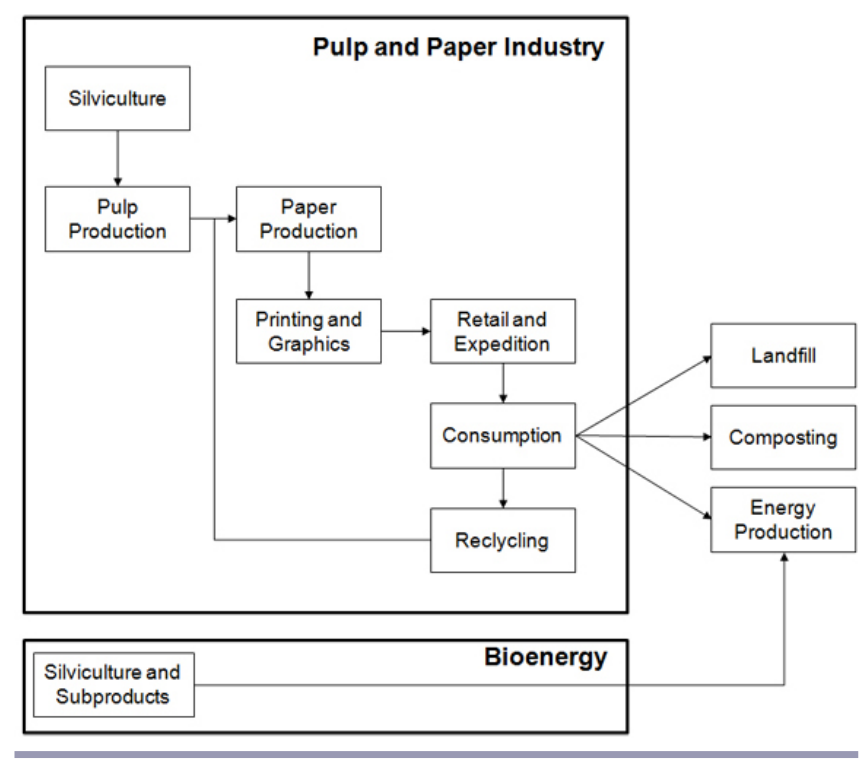

Bioenergy production stands were simulated with an adapted version of the Globulus model developed from spacing trials data to simulate WP stands. To provide more trustworthy simulation results for highly dense stands, research on the productivity of bioenergy plantations is needed to provide data for a new model to be developed for this purpose based on E. globulus trials, or any other variety/species.

Increasing new pulp plantation areas could be an answer to satisfying wood demand. However, when discussing the potential conflict between bioenergy and pulp, it has to be taken into account the fact that eucalyptus is an exotic species and that the Nature and Biodiversity Conservation Institute (ICNB) has made efforts to classify it as an invasive species. Eucalyptus is considered by many not to fit local natural ecosystems. Given this pressure, eucalyptus forest area is not likely to increase much more in the future. A solution may be the intensification of silviculture to improve productivity and an improvement of management in a large proportion of the privately owned eucalyptus stands. Apart from this, the situation of the pulp industries in Portugal has to be considered. In 2008 wood imports represented $13.1 \%$ of wood consumption, while in 2010 the number raised up to $26.8 \%$. This is partly due to severe fires that occurred in the past which have depleted forest resources (CEPA 2009, CELPA 2011). Moreover, after the investment made by pulp and paper industries to double production capacity while facing a $52.6 \%$ decline of raw material when compared to 2008 (CELPA
2010), it is expected that imports will grow even more so that wood demand can be meet in the future. At the same time, in 2010 exports of pulp and paper have increased $3.1 \%$ when compared to 2009.

\section{CONCLUSIONS}

The simulations show that, under the current situation in Portugal and assuming that biomass demand is satisfied before bioenergy demand, increasing biomass demand up to the considered level did not have a major impact on wood available for pulp production, as long as bioenergy plantations are established to secure the supply of biomass demand avoiding wood from being used as energy. However, forest was not capable of satisfying wood demand even when biomass demand was disregarded. This situation could be less problematic if higher afforestation levels were considered. However, eucalyptus is a controversial species and a big expansion in terms of area might be excluded. Therefore, pulp and paper industries will have to focus on alternative measures to increase productivity and wood quality in order to satisfy wood demand and reduce or maintain their level of imports, such as the use of improved genetic material and sustainable forest management practices and also by enforcing fire prevention in order to reduce burned areas.

Some of the assumptions and constraints that were used resulted from the deficient information regarding the present situation of bioenergy production in Portugal. This lack of reporting resulted in several assumptions that cannot be demonstrated for the time being and that were deliberately exaggerated, in order to explore the future biomass availability, such as the amount of eucalyptus consumed in each plant and the exact number and capacity of future plants to be set. However, the simulation results under the different scenarios showed that the model can be used to forecast wood available for pulp and paper industries and the potential biomass deriving from forests to supply the demands. Furthermore, it allows assessing the contribution of each biomass source to meet biomass demand, but also set up a landmark to evaluating future scenarios. SIMPLOT's predictions have been evaluated using data from consecutive inventories and the results have proven its accuracy (Barreiro 2012). This gives more credit to the results making the simulator an extremely valuable tool for eucalyptus in Portugal as well as for any other species provided that the new speciesspecific growth functions are introduced into the growth module.

Responses to this article can be read online at: http://www.ecologyandsociety.org/voll7/iss2/art14/ responses/ 


\section{Acknowledgments:}

The research leading to these results is part of the PhD studies of the first author and is supported by grant SFRH/ BD/31239/2006 of the Portuguese Foundation for Science and Technology (FCT). Funding was also received from the European Community's Sixth Framework Programme FP6 EFORWOOD-IP project (contract 518128) and Seventh Framework Programme FP7/2007-2013 under grant agreement $n^{\circ} \mathrm{CP}-I P$ 228589-2 AFORE. We would also like to thank the anonymous reviewers for their valuable comments and the editor for improving the text readability.

\section{LITERATURE CITED}

Abell, T. M. 2005. Forestry and biomass production. Lessons from the temperate regions and the tropics. International Conference on the Issues for Sustainable use of Biomass Resources for Energy. Colombo, Sri Lanka. [online] URL: www.nri.org/projects/biomass/conference proceedings p2.htm

Altri, SGPS, S. A. (Altri). 2010. Relatório do Conselho de Administração - Contas Consolidadas 2009. [online] URL: http://en.altri.pt/pulpandpaper/Celbi/

Alves, G. R. 1996. Estimação de biomassa total e de madeira em eucaliptais jovens de segunda rotação. Dissertation. Instituto Superior de Agronomia, Universidade Técnica de Lisboa, Lisbon, Portugal.

Associação da Indústria Papeleira (CELPA). 2006. Contribuição para a politica das alterações climáticas. CELPA, Associação da Indústria Papeleira [online] URL:

http://www.celpa.pt/images/pdf/art213 brochura contribucao. pdf

Associação da Indústria Papeleira (CELPA). 2009. Boletim Estatístico 2008 da Associação da Indústria Papeleira. CELPA Editores. Lisbon, Portugal.

Associação da Indústria Papeleira (CELPA). 2010. Boletim Estatístico 2009 da Associação da Indústria Papeleira. CELPA Editores. Lisbon, Portugal.

Associação da Indústria Papeleira (CELPA). 2011. Boletim Estatístico 2010 da Associação da Indústria Papeleira. CELPA Editores. Lisbon, Portugal.

Autoridade Florestal Nacional (AFN). 2010. Inventário Florestal Nacional. IFN 200-2006. Portugal Continental. Autoridade Florestal Nacional, Ministério da Agricultura do Desenvolvimento Rural e das Pescas, Lisbon, Portugal.

Baptista, F. O., and R. T. Santos. 2005. Os Proprietários Florestais. Celta Editora, Lisbon, Portugal.

Barreiro, S. 2012. Development of forest simulation tools for assessing the impact of different management strategies and climatic changes on wood production and carbon sequestration for eucalyptus in Portugal. Dissertation, Technical University of Lisbon, Lisbon, Portugal.

Barreiro, S., and M. Tomé. 2011. SIMPLOT: Simulating the impacts of fire severity on sustainability of eucalyptus forests in Portugal. Ecological Indicators 11:36-45. http://dx.doi.org /10.1016/j.ecolind.2009.06.015

Carneiro, M., A. Fabião, M.C. Martins, C. Cerveira, C. Santos, C. Nogueira, M. Lousã, L. Hilário, André Fabião, M. Abrantes, and M. Madeira. 2007. Species richness and biomass of understory vegetation in a Eucalyptus globulus Labill. coppice as affected by slash management. European Journal Forest Research 126:475-480. http://dx.doi.org/10.1007/s10342-006 -0143-5

Diário da República (DRE). 2005a. Diário da República Electrónico, Presidência do Conselho de Ministros, Resolução do Conselho de Ministros n 169/2005, Diário da Repúblicai Série-B, $n^{\circ} 204,24$ October 2005, Lisbon, Portugal. [online] URL: http://dre.pt/pdf1sdip/2005/10/204B00/61686176.pdf

Diário da República (DRE). 2005b. Diário da República Electrónico, Ministério das Actividades Económicas e do Trabalho, Decreto-Lei $\mathrm{n}^{\mathrm{o}} 33-\mathrm{A} / 2005$ de 16 de Fevereiro, Diário da República -i Série-A no 33; 16 February 2005, Lisbon, Portugal. [online] URL: http://dre.pt/pdf1sdip/2005/0 2/033A01/00020009.pdf

Diário da República (DRE). 2006. Diário da República Electrónico, Presidência do Conselho de Ministros, Resolução do Conselho de Ministros no 115/2006, Diário da República, 1.a série - $\mathrm{n}^{\circ} 180 ; 18$ September 2006, Lisboa, Portugal. [online] URL: http://dre.pt/pdf1sdip/2006/09/18000/68356881. pdf

Direcção Geral dos Serviços Florestais e Aquícolas (DGSFA). 1966a. Inventário ao Norte do Tejo - 1965-1966. Direcção Geral dos Serviços Florestais e Aquícolas, Lisbon, Portugal.

Direcção Geral dos Serviços Florestais e Aquícolas (DGSFA). 1966b. Inventário ao Sul do Tejo - 1965-1966. Direcção Geral dos Serviços Florestais e Aquícolas, Lisbon, Portugal.

Jones H. E., M. Madeira, L. Herraez, J. Dighton, A. Fabião, F. González-Rio, M. Fernandez Marcos, C. Gomez, M. Tomé, H. Feith, M. C. Magalhães, and G. Howson. 1999. The effect of organic-matter management on the productivity of Eucalyptus globulus stands in Spain and Portugal: tree growth and harvest residue decomposition in relation to site and treatment. Forest Ecology and Management 122:73-86. http: //dx.doi.org/10.1016/S0378-1127(99)00033-X

Madeira A. C., M. Madeira, A. Fabião, P. Marques, and M. Carneiro. 2010. Impact of harvest residues, fertilisers and Nfixing plants on growth and nutritional status of young Eucalyptus globulus plantations, under Mediterranean 
conditions. European Journal of Forest Research 129:591601. http://dx.doi.org/10.1007/s10342-010-0359-2

Nabuurs G. J., A. Pussinen, J. van Brusselen, and M. J. Schelhaas. 2007. Future harvesting pressure on European forests. European Journal Forest Research 126:391-400. DOI 10.1007/s10342-006-0158-y. http://dx.doi.org/10.1007/s1034 2-006-0158-y

Pereira, T. C., T. Seabra, H. Maciel, and P. Torres. 2010. Portuguese national inventory report on greenhouse gases, 1990-2008. Agência Portuguesa do Ambiente, Ministério do Ambiente e do Ordenamento do Território, Amadora, Portugal.

Ribeiro, F., P. Soares, M. Tomé, D. Cadete, and P. Pina. 1997. Determination of initial stand density that optimizes the system production of Eucalyptus globulus Labill. in Portugal. Pages 125-129 in Proceedings of IUFRO Conference on silviculture and improvement of eucalypts. Volume 3. Embrapa, Centro Nacional de Pesquisa de Florestas, Colombo, Brazil.

Sims, R. E. H., K. Senelwa, T. Maiava, and B. T. Bullock. 1999. Eucalyptus species for biomass energy in New ZealandPart II: Coppice performance. Biomass and Bioenergy 17:333-343. http://dx.doi.org/10.1016/S0961-9534(99)00043-4

Soares, J., L. Leal, P. Canaveira, F. Goes, and A. Fialho. 2007. Porquê cultivar o eucalipto? Pages 185-219 in Público comunicação Social, SA and Fundação Luso-Americana para o Desenvolvimento editors. Árvores e Florestas de Portugal. Pinhais e Eucaliptais - A floresta cultivada. Lisbon, Portugal.

Soares, P., and M. Tomé. 2003. GLOBTREE: an individual tree growth model for Eucalpytus globulus in Portugal. Pages 97-110 in A. Amaro, D. Reed, and P. Soares, editors. Modelling forest systems. CABI Publishing, Cambridge, Massachussetts, USA.

Tomé, M., A. Meyer, T. Ramos, S. Barreiro, S. P. Faias, and A. Cortiçada. 2007a. Relações hipsométricas desenvolvidas no âmbito do tratamento dos dados do Inventário Florestal Nacional 2005-2006. Publicações GIMREF. RT 3/2007. Centro de Estudos Florestais, Instituto Superior de Agronomia, Universidade Técnica de Lisboa, Lisbon, Portugal.

Tomé, M., P. Soares, and T. Oliveira. 2006. O modelo GLOBULUS 3.0. Dados e equações. Publicações GIMREF RC2/2006. Centro de Estudos Florestais, Instituto Superior de Agronomia, Universidade Técnica de Lisboa, Lisbon, Portugal.

Tomé, M., J. Tomé, F. Ribeiro, and S. P. Faias. 2007b. Equação de volume total, volume percentual e de perfil do tronco para
Eucalyptus globulus Labill. em Portugal. Silva Lusitana 15 (1):25-29.

United Nations. 1998. Kyoto protocol to the United Nations framework convention on climate change. United Nations Climate Change Secretariat, Bonn, Germany. [online] URL: http://unfccc.int/resource/docs/convkp/kpeng.pdf 
APPENDI X 1. Detailed description of the simulation parameters and forest management approaches considered in the case study.

Wood-production stands (WP) are managed as a planted stand followed by two coppice stands before replanting occurs with final harvest, whereas bioenergy production stands (BP) are managed as a planted stand followed by three coppiced stands. All rotations in BP stands are characterized by a rotation length of 5 yrs. Table A. 1 summarizes the silvicultural operations practiced for each FMA, rotation, and age.

Table A.1 Detailed description of the forest management approach considered in the case study.

\begin{tabular}{|c|c|c|c|}
\hline FMA & Rotation & Age & Silvicultural operations \\
\hline \multirow{7}{*}{ WP } & \multirow{4}{*}{1} & 1 & Planting (1250 trees/ha) and fertilization at planting \\
\hline & & 2 & Weed control and beating up \\
\hline & & 4,7 and 11 & Weed control and fertilization \\
\hline & & 16,22 and 28 & Weed control \\
\hline & \multirow{3}{*}{2 and 3} & 3 & Weed control and shoot selection ( 1.6 sprouts per stool) \\
\hline & & 5 and 8 & Weed control and fertilization \\
\hline & & $12,17,23$ and 29 & Weed control \\
\hline \multirow{7}{*}{$\mathrm{BP}$} & \multirow{4}{*}{1} & 1 & Planting (5000 trees/ha) and fertilization at planting \\
\hline & & 2 & Weed control and beating up \\
\hline & & 4 & Weed control and fertilization \\
\hline & & 5 & Final harvest \\
\hline & \multirow{3}{*}{2 until 3} & 1 & Fertilization \\
\hline & & 2 & Weed control and fertilization \\
\hline & & 4 & Weed control \\
\hline
\end{tabular}

For WP final harvest can occur at any stand stage as long as the stand is older than the minimum age for harvesting defined by the simulation parameter.

The usual age for even-aged stands final felling was considered to be $12 \mathrm{yrs}$, but it can vary according to the need for wood. The harvesting method/system consists in removing tops, bark, and branches. Table A.2 contains the simulation parameters used in the simulations.

Table A.2 Simulation parameters considered in the case study.

\begin{tabular}{|c|c|}
\hline Number of years to project & 42 \\
\hline Minimum age for industrial use of wood after a fire (years) & 5 \\
\hline Proportion wood industrially used after fire & 0.6 \\
\hline Proportion of old/sparse non-industrial stands harvested & 0.1 \\
\hline Proportion uneven-aged stands harvested & 0.1 \\
\hline $\begin{array}{l}\text { Minimum age for harvesting } \\
\text { Nr of age classes } \\
\text { Even-aged stands harvesting probability: } \\
\text { Age }=8 \\
\text { Age }=9 \\
\text { Age }=10 \\
\text { Age }=11 \\
\text { Age }=12 \\
\text { Age }>12\end{array}$ & $\begin{array}{l}8 \\
6 \\
0.1 \\
0.2 \\
0.3 \\
0.4 \\
0.5 \\
0.95 \\
\end{array}$ \\
\hline $\begin{array}{l}\text { Harvesting system: } \\
\text { Bark } \\
\text { Branches } \\
\text { Top } \\
\text { Tops and branches }\end{array}$ & $\begin{array}{l}1 \\
1 \\
1 \\
0\end{array}$ \\
\hline $\begin{array}{l}\text { Assortments: } \\
\text { Number of assortments } \\
\text { Id } \\
\text { Label } \\
\text { Top diameter }(\mathrm{cm}) \\
\text { Log length }(\mathrm{m}) \\
\text { Value }\left(€ / \mathrm{m}^{3}\right) \\
\end{array}$ & $\begin{array}{l}1 \\
12 \\
\text { Pulp biomass } \\
5- \\
2- \\
4525\end{array}$ \\
\hline $\begin{array}{l}\text { FMA: } \\
\text { Number of FMA } \\
\text { FMA Id } \\
\text { Number of rotations } \\
\text { Maximum age of rotation }\end{array}$ & $\begin{array}{ll}2 & \\
1 & 2 \\
3 & 4 \\
30 & 5 \\
\end{array}$ \\
\hline
\end{tabular}

